\title{
Dickens's Dichotomous Formula for Social Reform In Oliver Twist
}

\author{
Taher Badinjki \\ Dept of English, Faculty of Arts, Al-Zaytoonah University of Jordan, Jordan \\ E-mail: tbadinjki@hotmail.com
}

Received: 19-08-2016

Published: 10-12-2016
Accepted: 22-10-2016

doi:10.7575/aiac.ijalel.v.5n.7p.209
Advance Access Published: November 2016

URL: http://dx.doi.org/10.7575/aiac.ijalel.v.5n.7p.209

\begin{abstract}
Oliver Twist was a direct appeal to society to take action against poverty, exploitation of children, oppression of women, and was meant to be a picture of the "dregs of life" in all their deformity and wretchedness. Among the most miserable inhabitants of the world of Oliver Twist, Nancy appears as a key figure. Dickens was anxious to expose the truth about such a woman because he believed it would be a service to society. Dickens's portrayal of Nancy illustrates the power of the dual conception of womanhood held at the time. On the one hand, a woman might be conceived as someone refined and somewhat remote from ordinary life like Rose Maylie. On the other hand, there was a certain fascination in a woman's degradation, even though that could be shown only indirectly. Nancy is a demonstration of the two elements combined together. Dickens took the ideal nature of womanhood and the depravity of the prostitute, and combined them in a remarkable dramatization which he had some right to claim was also true to life. The book is an astounding rebuttal of contemporary prejudice, and a call for more humane and liberal attitudes. These attitudes are based on the concepts that there is now a radically different way of looking at human nature, that everything ought to depend on what one is in oneself, and that it is only in love that humans can live purposefully and happily with each other.
\end{abstract}

Keywords: radical, moral conventions, social, womanhood, reform, depravity, victim

\section{Introduction}

Of the works of all great British authors of the 19th century who wrote on the social ills of the time, few can reach the same level of eloquence as Oliver Twist by Charles Dickens. In this book, Dickens attacked English institutions with a ferocity that had never since been approached, and was labelled by many critics and readers as a subversive writer, a radical, and, one may say, a rebel. Lord Chamberlain banned the book and considered it "dangerous to public peace" (Bolton, 1987), while the Regius Professor at Edinburgh saw it as "dangerously frank" (Aytoun, 1864), and Lady Carlisle commented on it saying "I know there are such unfortunate beings as pickpockets and street walkers ... but I own I do not much wish to hear what they say to one another" (Ford, 1955). Despite that, the book was reviewed overwhelmingly with admiration. It was read as a work of art, and the young Queen Victoria found it "excessively interesting" (Collins, 1971). How did Dickens manage to do that? The answer lies in his dichotomous formula for social reform which condemns the sin and tries to redeem the sinner. He managed to do it without making himself hated, and, more than this, the very people he attacked tolerated him so completely that he became a national institution himself. According to George Orwell, "In its attitude towards Dickens, the English public has always been a little like the elephant which feels a blow with a walking-stick as a delightful tickling" (1981).

The book contains undertones of criticism of the Victorian standards, and preaches sympathy for the underprivileged in society. It is a form of direct appeal to society to take action against poverty, exploitation of children, and oppression of women. In his "Preface" to the third edition (1841), Dickens wrote that he meant it to be a picture of the "dregs of life" in which he could show them "in all their deformity, in all their wretchedness, in all the squalid poverty of their lives; to show them as they really are, forever skulking uneasily through the dirtiest paths of life". Such a picture he believed was necessary, and it "would be a service to society" (Barnett, 1971).

Among the most miserable inhabitants of the world of Oliver Twist we encounter Nancy, a lost woman of the underworld. Dickens's powerful portrayal of Nancy showed that his knowledge of lost women was clinical and complete. How he acquired this knowledge is difficult to say, but we can presume that his early experience as a worker at Warren's Blacking Warehouse, and his early life at Bayham Street, "the poorest part of the London suburbs" (Forster, 1875), might have brought him in contact with prostitutes who had quarters there, and implanted in his sensitive and intelligent mind a true picture of the nature of these women, and of their miserable lives. In the same "Preface" (1841) he wrote that the "conduct and character" of Nancy had been suggested to his mind "long ago" by what he "often saw and read of, in actual life" around him. It is also likely that through his career as a court reporter, he frequently saw prostitutes brought before the bar, and he acquired experience of their lives and manners, and was later able to draw upon for the purpose of his fiction. 
Dickens was anxious to expose the truth about such a woman as Nancy. He told Forster "I hope to do great things with Nancy" (Collins, 1962). The characterization both revealed and concealed the subject. In a work of fiction meant for general reading and entertainment, Dickens clearly felt that there was a limit to the degree to which he could be outspoken.

\section{Discussion}

Nancy is not presented to the reader as a woman who basely sells herself for personal gain. She is presented as a victim, a youthful sacrifice to Fagin's greed. She had stolen for him when "a child not half as old as "Oliver and had been "in the same trade" of prostitution for "twelve years since" $(O T, 104)$. Such fall as there is, has been from a state of which she could never have been aware. She is the only member of Fagin's gang who is able to show sincere human feelings and selfless love. She feels a human sympathy for the prisoners when she passes a prison, and tells Sikes that if he were among them, she would "walk round and round the place till [she] dropped, if the snow was on the ground, and [she] hadn't a shawl to cover [her]" (OT, 99). Through her, Dickens "emphasizes the fact that even the vilest environment cannot utterly obliterate or corrupt the principle of good in its victims" (Johnson, 1953). Though Nancy has fallen as low as a woman can fall, yet deep in her heart there is still something of the woman's original nature left which links her with humanity. She is touched by Rose Maylie's compassion and acts as Oliver's protector and Sikes's tender and devoted "wife". "I cannot leave him," she says of Sikes to Rose Maylie, even "if I knew that I was to die by his hand at last" $(O T, 273)$. Her redemption is shown in human terms, although Dickens chose to justify it in the 1841 Preface as "emphatically God's truth... the truth He leaves in such depraved and miserable breasts... the last drop of water at the bottom of the weed-chocked well". When an offer' is made to abandon her miserable life with the gang, Nancy replies, (only after some inner struggle), "I am chained to my old life, I loathe and hate it now, but I cannot leave it" $(O T, 316)$. Undoubtedly, Dickens wants us to respect her for her ill-fated loyalty, and pity her unhappy position by satirizing the remarks heaped on her by righteous females, such as the house-maids in the little family hotel who exclaim,

It's no good being proper in this world,' said the first housemaid. 'Brass can do better than the gold what has stood the fire,' said the second. The third contented herself with wondering 'what ladies was made of;' and the fourth took the first in a quartette of 'Shameful!' with which the Dianas concluded (OT, 269).

Keith Hollingsworth believes that the origin of Nancy's character is the girl in the early sketch "The Hospital Patient", in which Dickens tells the story of a young woman who makes a last minute repentance on her death-bed and refuses to accuse the man who had brutally beaten and injured her. After summarizing the incidents of the sketch, Hollingsworth comments, "Bill Sikes and Nancy are here, and Nancy's unshakable devotion, her repentance, and her murder" (1963). Though this may be the origin, yet in Oliver Twist, Dickens succeeds in making Nancy a character of some complexity, and the conflict "between her devotion to Sikes and her pity for Oliver", as Edgar Johnson writes, "is wholly convincing" (1953).

The book illustrates the power of the dual conception of womanhood held at the time. On the one hand, a woman might be conceived as someone refined and somewhat remote from ordinary life like Rose Maylie. On the other hand, there was a certain fascination in a woman's degradation, even though that could be shown only indirectly. It is also a demonstration that the two elements may be combined together as we see in Nancy. For at first, Nancy is no more than a "stout and hearty" girl, like Betsy $(O T, 55)$. When she dreads to visit the police-station after Oliver's arrest, she winks and smiles to the company, and shows spirit in recapturing Oliver. Later, she realizes the evil she is involved in, expresses her contrition and shame, and demonstrates a positive capability of conversion. In creating her character, Dickens took these conventions, the ideal nature of womanhood and the depravity of the prostitute, and combined them in a remarkable dramatization which he had some right to claim was also true to life.

One of the sympathetic points about Nancy is that "she never had a chance, and that though she might have been different, it has been too late" (Fielding, 1965). She comes from an environment of squalor and had nowhere better to live than the "cold, wet, dirty streets" $(O T, 104)$, and no better company than "hunger, and riot and drunkenness" (OT, 271). Under the effects of Oliver's inherent goodness and innocence, and Rose Maylie's charitable attitude, the good side of her nature rebels, and her moral conscience starts to work, and from this point on in the novel, she works for good and makes the decisive move towards her salvation. She attacks Fagin and emerges as Oliver's only protector.

Kathleen Tillotson believes that Dickens's view of Nancy changed as he was writing the novel. She localizes the change in chapter sixteen, finding "nothing in the three previous chapters in which she appears" to anticipate "her emergence as Oliver's defender" (1966). In fact, Nancy does change in chapter sixteen, but it is not an arbitrary change. It seems to me that the inconsistencies between the early Nancy and the later Nancy are really logical steps in her moral growth and in Dickens's formula for social change. In his letter to Forster (3 November 1837), Dickens expressed his intention to do great things with Nancy if "I can only work out the idea I have formed of her, and of the female who is to contrast with her". This does show that Dickens formed his idea of the character in advance, and at the same time it suggests that he already had Rose Maylie and the encounter between the two in mind too. 
Nancy's change is made to seem the direct result of the influence of the angelically innocent Oliver. Nancy's kidnapping of Oliver occurs at the end of chapter fifteen, and Dickens's title for the next chapter is "Relates What Became of Oliver Twist, After He Had Been Claimed By Nancy". It seems to me that it might be more properly called "Relates What Became of Nancy, After She Had Been Claimed By Oliver Twist". Oliver's inherent goodness makes him utterly different from any character in Fagin's gang. He reminds Nancy of her own lost innocence. The sight of him, she says "turns me against myself" $(O T, 166)$. His influence begins immediately to work on her. After the kidnapping and on their way to Fagin's den in chapter sixteen, Oliver "felt" Nancy's "hand tremble; and, looking up in her face as they passed a gas-lamp, saw that it had turned a deadly white" $(O T, 99)$. She acts as "a surrogate mother" (Ayres, 1998) who tries to protect and shield Oliver. When he attempts to escape and is pursued by Fagin and two of his boys, Nancy stands before the door and tells Sikes, "keep back the dog, Bill... the child shan't be torn down by the dog, unless you kill me first" $(O T, 102)$. When Fagin returns with Oliver and takes up a club to punish him, Nancy bursts out,

You've got the boy, and what more would You have? Let him be-let him be, or I shall put that mark on some of you, that will bring me to the gallows before my time $(O T, 103)$.

Nancy's moral rebellion intensifies. She attacks Fagin passionately and curses him for what he has made her,

You villain! ... I thieved for you... I have been in the same trade $\cdots \bullet$ for twelve years.... You're the wretch that drove me to them long ago; and that'll keep me there, day and night, day and night, till I die! (OT, 1 04).

Through her contact with Oliver, Nancy becomes pure in heart. Her compassion for him seems to be prompted by nothing other than her womanly feeling, and his passive innocence. Even the boy himself senses that his power over Nancy is "her compassion for his helpless state" $(O T, 131)$. At the time of the robbery, it becomes clear that Nancy's drunkenness is a result of her attempt to drown her own sorrow and her guilt for the innocence Oliver is on the verge of losing.

The change in Nancy's moral stance is also stimulated by Rose Maylie's sympathetic attitude. The first words of Rose astonish and overcome her immediately, "Oh, lady, lady I", she said, clasping her hands passionately before her face, "if there was more like you, there would be fewer like me--there would-- there would!" (OT, 271). Rose Maylie is in fact a function rather than individual (Blount, 1968). She does not just change Nancy, she demonstrates what a woman really is--what Nancy really is too. Through her, Nancy realizes the gulf between her evil world and the virtuous world pursues good with energy and decisiveness and emerges as a power of good, a force that can defeat evil. She recognizes her sin, and tries to atone by risking her life to reveal the underworld plan to Rose and Mr Brownlow, which leads to her brutal death. Through Nancy's stimulated goodness, and through her positive response, Dickens pleads for a loving, sympathetic and above all humanitarian reform of society's "outcast".

Nancy's womanly feeling, her selfless love and devotion take her back to Sikes. Her return to him after revealing the plot against Oliver is both justified and necessary for the novel. It is precisely this loyalty and selflessness, this heroic love which she shows that transforms her into a woman who wins our love and respect. Hence her brutal and crushing death at the end excites our feelings of pity and sympathy. There is some parallel between Nancy and Agnes Fleming. The account of Agnes's death and love for the infant Oliver is also intended to excite our sympathy for her. She runs away from home to save her father and little Rose from disgrace, and like Nancy, "can do nothing but die".

Nancy dies on her knees, raising Rose Maylie's white handkerchief, an emblem of repentance and an outward symbol of salvation. "Saved from despair at the last moment", she expiates "her guilt in her innocent blood" (Cockshut, 1977). Though she is not allowed any earthly reward, yet in portraying her repentant death, there is an indication that forgiveness and a heavenly reward are possible. Again, there is a parallel with Oliver's mother, Agnes. The book closes with the suggestion that the "weak and erring" Agnes $(O T, 368)$ might return in spirit to the empty tomb hallowed by her son's love -- even if the tomb was in a church.

Though in Mr Brownlow's offer to Nancy of "a quiet asylum, either in England, or ... in some foreign country" (OT, 315 ), there is a hint at the idea of emigration as a possible solution to the problem of the repentant fallen woman--a solution which Dickens applied later in David Copperfield---yet the moral and the social climate of the thirties did not allow such a possibility to ripen, and the suggestion remained undeveloped.

\section{Conclusion}

Nancy's violent death must seem shocking, but this was possibly the only way left for Dickens to end her story. To the early Victorian readers "it is only just. Sexual offence, notwithstanding its more laudatory elements of love and devotion, is still sexual offence and must be wiped out before a God-fearing society can grant its absolution" (Kennedy, 1978). Her death does not come as a surprise. It has been hinted at in the novel more than once. In her meeting with Rose, Nancy expects it, 
Look at that dark water. How many times. Do you read of such as I who spring into the tide, and leave no living thing, to care for, or bewail them. It may be years hence, or it may be only months, but I shall come to that at last $(O T, 316)$.

Nancy's premonition came true, but instead of the "watery death", Dickens gave her a more tragic and moving end. The murder scene in which Sikes batters her to death not only succeeded in arousing the reader's feelings of pity and sympathy for Nancy, it also became one of Dickens's reading passages which obsessed him on his reading-tours and was one of the causes which hastened his own death (Johnson, 1953). Describing the immediacy of the effect of this scene on his audience, Dickens wrote,

At Clifton the "Murder" brought about "a contagion of fainting. And yet the place was not hot. I shall think we had from a dozen to twenty ladies borne out, stiff and rigid, at various times. It became quite ridiculous" (Johnson, 953).

In addition to its sympathetic effects, Nancy's tragic end served moralistic needs. On the one hand, it was the only way to satisfy the righteous moralists of the period, and avoid their attack. Through her harrowing death, Dickens tends to show her as a victim of circumstances rather than a sinner. Oliver's half-sister, Rose, was at one time (apparently falsely), said to be illegitimate. The novel emphatically tries to show that it is what people are in themselves, which is important, not the circumstances of their parentage or birth. In certain respects it is an astounding rebuttal of contemporary prejudice and attitudes. In others, however, it supports new attitudes to which little attention has been paid. These are that there is now a radically different way of looking at human nature, and that everything ought to depend on what one is in oneself.

Nancy's repentance after her "fall" is so elevating that though she dies before the end of the novel, she is refined to a ghostly figure and a pair of eyes that come back to haunt the evil world and destroy it. The novel is a plea for love and sympathy. It is the teaching of Henry Fielding, expressed with the power of Dickens. Its teaching is that it is only in love that humans can live purposefully and happily with each other. The prostitute must be reformed if respectable society is to survive, and the only way to reform her is to show her a humanitarian feeling of love and sympathy and a Christian readiness to forgive.

\section{References}

Ayres, B. (1998). Dissenting Women in Dickens' Novels: The Subversion of Domestic Ideology. London: Greenwood Press.

Aytoun, W. E. (1864). Advice to an Intending Serialist in Blackwood's Magazine, 60(1), 590-605.

Barnett, G. L. (1971). Nineteenth-Century British Novelists on the Novel. New York: Appleton- Century-Crofts, Meredith Corporation.

Blount, T. (1968). Dickens, The Early Novels. London: Longman.

Bolton, P. H. (1987). Dickens Dramatized. London: Mansell.

Cockshut, A. O. J. (1977). Man and Woman, A Study of Love and the Novel 1740-1940. London: Collins.

Collins, P. (1962). Dickens and Crime. London: Macmillan.

Collins, P. E. (1971). Dickens, The Critical Heritage. London: Routledge and Kegan Paul.

Dickens, C. (1962). Oliver Twist. Oxford: Clarendon Press. . Subsequent references appear in the text as OT.

Fielding, K. J. (1965). Charles Dickens, A Critical Introduction. London: Longmans, Green and Co.

Ford, G. H. (1955). Dickens and His Readers, Aspects of Novel Criticism Since 1836. Princeton, Princeton University Press.

Forster, J. (1875). The Life of Charles Dickens. Vol. I. 18120-1842. Boston, James R. Osgood \& Company. Hollingsworth, K. (1963). The Newgate Novel, 1830-1847; Bulwer, Ainsworth, Dickens \& Thackeray. Detroit, Wayne State University Press.

House, H. (1979). The Dickens World. Oxford, OUP.

Kennedy, G. E. (1978). Women Redeemed, Dickens's Fallen Women. Dickensian, 74(1), 42-47.

Johnson, E. (1953). Charles Dickens, His Tragedy and Triumph. 2vols. London, Victor Gollanz Ltd.

Orwell, G. (1981). A Collection of Essays. Orlando, Houghton Mifflin Harcourt Publishing Company.

Tillotson, K. (1966). "Introduction" in Oliver Twist. Oxford, Clarendon Edition. 